NBER WORKING PAPER SERIES

\title{
THE SUPPLY OF ENVIRONMENTALISM
}

\author{
Edward L. Glaeser \\ Working Paper 19359 \\ http://www.nber.org/papers/w19359
NATIONAL BUREAU OF ECONOMIC RESEARCH
1050 Massachusetts Avenue
Cambridge, MA 02138
August 2013

Glaeser thanks the Taubman Center for State and Local Government for financial support. Kristina Tobio provided superb research assistance. Matthew Kahn provided helpful comments. The views expressed herein are those of the author and do not necessarily reflect the views of the National Bureau of Economic Research.

The author has disclosed a financial relationship of potential relevance for this research. Further information is available online at http://www.nber.org/papers/w19359.ack

NBER working papers are circulated for discussion and comment purposes. They have not been peerreviewed or been subject to the review by the NBER Board of Directors that accompanies official NBER publications.

(C) 2013 by Edward L. Glaeser. All rights reserved. Short sections of text, not to exceed two paragraphs, may be quoted without explicit permission provided that full credit, including $\bigcirc$ notice, is given to the source. 
The Supply of Environmentalism

Edward L. Glaeser

NBER Working Paper No. 19359

August 2013

JEL No. Q0,Q5

\begin{abstract}
$\underline{\text { ABSTRACT }}$
Long before economics turned to psychology, environmentalists were nudging and framing and pushing their cause like highly gifted amateur psychologists. Their interventions seem to have changed behavior by altering beliefs, norms and preferences, but because psychological interventions are often coarse, inadvertent, offsetting side effects occur. After discussing the interplay between environmental preference-making and economics, I turn to three areas where strong, simple views have spread-electric cars, recycling and local conservation efforts. In all three areas, environmental rules of thumb can lead to significant, adverse environmental side effects. Local environmentalism, for example, may increase carbon emissions by pushing development from low emission areas, like coastal California, to high emissions areas elsewhere. I end by discussing how economic analysis of the political market for ideas can make sense of the remarkable disparity of views on global warming.
\end{abstract}

Edward L. Glaeser

Department of Economics

315A Littauer Center

Harvard University

Cambridge, MA 02138

and NBER

eglaeser@harvard.edu 


\section{Introduction}

Environmental activists have long specialized in influencing beliefs and preferences through books, like Paul Ehrlich’s The Population Bomb, films like “An Inconvenient Truth” and public relations campaigns, like Keep America Beautiful’s “Crying Indian” commercials. These interventions appear to have some influence on behavior, like recycling and hybrid car purchases, and policies, like the Clean Air Act, although their simple prescriptions (Lee and Kotler, 2006), may suggest responses that are imperfect or even counter-productive. ${ }^{2} \quad$ Just as there is value in behavioral environmental economics that embeds psychological wisdom into proposed policy interventions (Shogren and Taylor, 2008), there is value in using economics to understand the causes and impact of the supply of environmental preferences and beliefs. Psychology and economics are complements, not substitutes.

In this essay, I discuss three core questions surrounding endogenous environmentalism. What determines when environmentalism is most likely to be spread and when it is likely to elicit a backlash? What determines whether the supply of environmentalism is benign or harmful? Finally, what more traditional policies complement the supplement of environmentalism, to expand its positive effects and counteract its shortcomings?

In Section II, I discuss the nature of supplied environmentalism, which is a crucial first step to understanding all three questions. Successful environment-related "psychological” interventions, such as Rachel Carson’s Silent Spring, first build empathy for the environment and wildlife and then argue that some activity, like using pesticides or littering, causes environmental damage. When they work, these interventions motivate policy action or individual behavior by

\footnotetext{
${ }^{2}$ More recycling can mean fewer trees (Darby, 1973); fuel efficient engines can mean more energy usage (Jevons,
} 1865). 
providing information, generating psychic Pigouvian taxes on the vilified activity, or creating a social norm.

Standard economic reasoning suggests that we should expect to see private environmental campaigns, when there is an organized body of capable persuaders with strong incentives to push a particular message. Reductions in the cost of persuasion will also generate more supplied environmentalism, but low persuasion costs will also increase the supply of counter-environmentalism. Normatively, environmental messages are more likely to be beneficial when they create psychic subsidies, rather than psychic taxes, and when the desired behavioral adjustment is straightforward. Complementary policies start by recognizing the shortcomings of environmental campaigns, and adjusting on the relevant margins.

After discussing endogenous environmentalism abstractly, I turn to four areas involving psychological intervention and economic analysis: electric cars, recycling, local land use restrictions and the debate over global warming. Section III discusses interventions, like a prohybrid car campaign, that effectively reduces the marginal cost of an environmentally harmful activity. In this case, there will be an offsetting behavioral response, which Pigouvian taxes can rectify. In some cases, the optimal tax may even be higher than the tax in the absence of the proHybrid car campaign.

In Section IV, I discuss cases, like recycling, when the intervention distorts the price to suppliers of the relevant commodity. In this case, the appropriate policy response may be an offsetting subsidy. In the fifth section, I turn to the perverse consequences that can come from local environmentalism that block new construction. Optimal policy design here may involve building subsidies that offset the local environmentalists in areas with benign climates and taxes 
in areas with extreme climates that don't have local environmentalists. The sixth section addresses the supply of counter-environmentalism in the debate over global warming. This section mainly illustrates the supply of environmentalism and counter-environmentalism. The final section concludes.

\section{The Supply of Environmentalism}

Environmental beliefs, norms and preferences are neither exogenous nor immutable, but heterogeneous, volatile (Lorenzoni and Pidgeon, 2006) and surely socially formed (Van Liere and Dunlap, 1980). Figure 1 shows the responses to the Gallup Poll's questions about global warming. ${ }^{3}$ Respondents in different countries were asked whether they thought that "rising temperatures are a result" of either "human activity” or "natural causes" and whether global warming is a "serious" or "somewhat serious" threat to themselves or their families. Answers to the second question could quite rationally differ from country-to-country, as the residents of Greenland presumably have far less to lose from global warming than the residents of Brazil.

A rational Bayesian framework would suggest that answers to the first question, the causes of Global Warming, shouldn’t differ significantly across space, as long as everyone has access to the same sources of knowledge about such a scientific question. Conversely, a view in which beliefs are shaped by social influence (as in Asch, 1955) suggests far more variation. Figure 1 shows that responses to the two questions are tightly linked (the correlation coefficient is 77 percent), and that there is remarkable heterogeneity across the world in the two variables. The residents of Iceland understandably see little threat in global warming, but they also believe

\footnotetext{
${ }^{3}$ Whitmarsh (2009) discusses the differences in public responses to different phrasing on climate change related questions.
} 
that temperature increases reflect natural factors not human activity. South African and Saudi residents hold similar views. By contrast, more than ninety percent of the residents of Korea and Japan believe that global warming is man-made and the overwhelming majority of respondents believe that global warming is a threat.

Numerous analysts (Basu, 2005, The Economist, 2009) have argued that poorer countries are likely to bear the biggest brunt from climate change, but richer country respondents seem far more concerned with climate change. The correlation between the log of per capita Gross Domestic Product (GDP) and seeing global warming as a threat is 57 percent. The connection may just reflect the fact that poorer people have so many other things to worry about, but it could just also be explained by a more robust market for ideas in wealthier countries.

This interpretation is also supported by the positive correlation between democracy (measured by the Polity IV index of democracy and autocracy) and belief that global warming is a threat. There is also a statistically significant 33 percent correlation between the logarithm of per capita GDP and the stated belief that global warming is the result of human activity, and a similar 30 percent correlation with democracy.

In this section, I discuss the endogenous formation of environmentalism and highlight four implications of the supply of environmentalism. First, there will be a strong bias towards simple environmental rules, since simple rules are far easier to convey to a mass audience. Second, if environmentalism creates a social norm where environmental actions signal pro-social preferences (or some other positive attribute), then this will create an added bias towards observable actions. Third, since incentives will impact supply, environmentalism will be skewed towards behavior in which suppliers have a financial or other political motive. Fourth, 
when environmental action will harm any well-organized interest group, then environmental persuasion will elicit countervailing persuasion that may be overwhelming.

\section{Green Persuasion}

Volumes on environmental marketing (e.g. Polonsky and Mintu-Wimsatt, 1995) have long pushed an approach to "selling" environmentalism that emphasizes the richness of human psychology. No explicit psychological research may have gone into the "Crying Indian" campaign, but the leader of the campaign's book on The Art of Cause Marketing tells “cause” marketers to write ads that are "sensitive to the psychology of the person whose behavior you wish to change" (Earle, 2002).

Similarly, while environmental writers such as Henry David Thoreau, John Muir, Rachel Carson and Paul Ehrlich, who may not have been trained in psychology (Carson did take at least one class) but whose work displays a remarkable ability to generate empathy for environmental causes. Humans appear to readily feel empathy for animals, especially when they are large and attractive (Metrick and Weitzman, 1996). Carson begins Silent Spring, with her "fable for tomorrow" where a town "where all life seemed to live in harmony" was beset by "some evil spell” (pesticides) that killed the birds and left “a spring without voices.”

It is hard to rigorously document the impact of campaigns like the "Crying Indian," but the Ad Council claims that "During the height of the campaign, Keep America Beautiful reported receiving more than 2,000 letters a month from people wanting to join their local team” and that "By the end of the campaign, Keep America Beautiful local teams had helped to reduce litter by as much as $88 \%$ in 300 communities, 38 states, and several countries.” Indeed, the only two public service campaigns listed by Ad Age among the top fifty advertising campaigns 
of the $20^{\text {th }}$ century concern the environment: the "Crying Indian” and "Smokey the Bear." More generally, the efficacy of environmental campaigns is demonstrated by the enormous popularity of Green Parties in Europe, the proliferation of green products, ${ }^{4}$ and surveys suggesting that large portions of the population recycle (Oskamp et al, 1991).

What determines the supply of environmentalism? Psychologically-effective environmental influence on behavior is generated through a market process, where interested parties invest in changing the behavior of others. That view implies that the incentives of influence-suppliers will partially determine the nature of environmental beliefs and preferences, especially when there is a congruence of the incentive to supply with the ability to persuade.

A simple economic model would suggest that any widespread social change requires individuals with incentives and enough cooperation to internalize the free-rider problem, who have access to relatively low-cost tools of persuasion. Similarly, individuals, groups and companies with contrary incentives and similar access to the tools of persuasion will try to generate counter-environmentalism. The relative success of those two groups in different countries presumably explains some measure of the heterogeneity in beliefs about global warming discussed above.

In the case of environmentalism, incentives come from at least three sources: pecuniary motives of entities that sell goods, like hybrid cars, that can be seen environmentally helpful, non-pecuniary selfish motives, like the desire of homeowners to prevent nearby new construction or the desire of politicians to appear altruistic, or purely altruistic motives. ${ }^{5}$ The first two sets of motives are easy for economists to analyze and use to form predictions. The role of altruism

${ }_{5}^{4}$ Clifford and Martin (2011).

${ }^{5}$ Scores of celebrities have visibly adopted low emissions forms of transportation, either to encourage such behavior or show off their own environmentalist leanings. 
provides less empirical bite, since we are treating the supply of environmental altruism as endogenous, but it does suggest that environmentalism is self-reinforcing. If environmental beliefs elicit environmental persuasion, then this creates a social multiplier, where initial investments can snowball creating a social multiplier (Glaeser, Sacerdote and Scheinkman, 2003), as some of the individuals who were persuaded by first movers, such as Thoreau and Carson, may themselves become suppliers of environmentalism.

When the motives of environmental suppliers reflect group-level benefits, then organizations that reduce free-riding become critical and these have a long history in environmentalism. The $19^{\text {th }}$ century “Boone and Crockett Club” was founded in 1887 by Theodore Roosevelt, Gifford Pinchot and William Tecumseh Sherman to protect forests. Not incidentally, the group's objectives would allow dedicated sportsmen, like Roosevelt, to continue their recreational hunting. The Sierra Club and the Audubon Society were other late $19^{\text {th }}$ century institutions meant to protect nature. "Keep America Beautiful” was founded in 1953 to reduce littering. These groups act both to directly influence public policy, as the Audubon Society did when it litigated to end the use of DDT, and also engage in public campaigns aimed at creating more environmentally sensitive behavior.

A third factor influencing supply is the cost of persuasion and the ability to become part of widespread public discourse (Hilgartner and Bosk, 1988). Books and articles were the initial persuasion tools, but successive rounds of new media have offered new means of acquiring access to diverse listeners (Mutz and Martin, 2001). Today, a host of websites offer assistance to school teachers aiming to increase environmental awareness, and official curricula call for 
teaching environmental messages like "the importance of the wetlands for human survival.”6 Lower costs of persuasion will also make it cheaper for anti-environmentalists to spread countermessages.

The ability of green persuasion to elicit a backlash is particularly obvious in the political sphere, where different parties may try to over or under emphasize environmental risks or reframe issues (Jacoby, 2000, Nelson and Kinder, 1996) depending upon the connection between those beliefs and their other preferences. In this way, the supply of environmental beliefs resembles the political supply of ethnic hatred discussed in Glaeser (2005). A party committed to support labor unions in the United States might emphasize the environmental costs of importing manufactured goods from abroad. A party committed to domestic energy production might attempt to minimize any risks from carbon emissions. The wider the division between the parties on environmentally-relevant policies, such as domestic energy production, the more heated environmental rhetoric will become. The eventual outcome will depend on the overall success of the political actors most closely aligned with environmental issues.

\section{Forms of Endogenous Environmentalism}

We can analyze the supply of environmentalism without understanding the nature of the environmentalism that is supplied, but to make public policy inferences we need to better understand supplied environmentalism. There are at least three natural interpretations of environmental campaigns, which parallel the interpretations of more standard advertising. Most simply, both advertising and environmental campaigns may just be providing information to

\footnotetext{
${ }^{6}$ Massachusetts Department of Education (2006).
} 
cognitively sophisticated or more limited citizens. ${ }^{7}$ According to this view, before Silent Spring, Americans didn't know that pesticides killed birds. After the book, they knew and changed their behavior accordingly. While there is assuredly some truth to this view, this interpretation can explain environmental voting more readily than private self-sacrificing environmental behavior.

If environmental campaigns only informed rational people of the existence of negative externalities, then these would have a very modest impact on behavior, such buying hybrid cars, given the modest levels of altruism that we observe elsewhere in human life. ${ }^{8}$ Moreover, the widely divergent environmental beliefs across the population are difficult to reconcile with canonical Bayesianism (Aumann, 1976). ${ }^{9}$ In many of the most compelling environmental campaigns, like the "Crying Indian,” it is hard to actually identify any new information.

A second way to understand the impact of these environmental campaigns is that they move society to a different equilibrium in a repeated signaling game. As an example, assume that a fraction of humanity is good, i.e. altruistic or pro-social, the rest of us are selfish, and that all of us are interested in persuading others that we are good, perhaps because they will trust us in other transactions. Assume further that there is some costly action that yields an environmental benefit, such as reducing energy use or not littering, and that good people are slightly more likely to find that action appealing even if no one observed the action. Even if no one would undertake the action if it were not seen, since all people want to be known as good, they may be willing to do the Green thing in order to be seen as good.

\footnotetext{
${ }^{7}$ Slovic (2000) discusses the complexities in public risk perceptions. Leiserowitz (2006) connects risk attitudes with attitudes to climate change policies.

${ }^{8}$ Goeree, Holt and Laury (2002) estimate an altruism parameter of around .1, meaning that their individuals are willing to sacrifice ten cents to create one dollar worth of benefits for the group.

${ }^{9}$ The limits to Aumann's analysis are suggested by the wide disparity of opinions about the dangers of global warming, even within the scientific community (Nordhaus, 1994). Althaus (1998) discusses the general information asymmetries within the American polity.
} 
This type of game can readily yield multiple equilibria for a common set of parameter values. In one equilibrium, no one undertakes the environmental action, and no one thinks too badly of people who aren't environmentally conscious. ${ }^{10}$ In a second equilibrium, everyone undertakes the environmental action, because if they didn’t, they would be thought to be selfish. According to this view, public relations campaigns work by converting society from an "everyone litters" equilibrium (where no one is thought to be bad because they litter) to a "no one litters" equilibrium (where anyone who litters is thought to be bad). ${ }^{11}$ When it comes to hybrid cars, the equilibrium shift is presumably from an equilibrium where no one buys and no one assumes that buyers are pro-social, to an equilibrium in which pro-social people buy hybrids. ${ }^{12}$ According to this view, environmental campaigns transform environmental actions into a costly signal of pro-social tendencies, and those actions become privately rational because no one wants to be seen as being selfish. The cost of environmentalism is worth paying because of the expected benefits of future relationships.

If environmental campaigns create signaling equilibria, then these campaigns must focus towards highly observable and generally simple environmental actions. In the case of littering, the losses from simplicity and observability were probably slight, for littering is a simple, observable thing by its nature. Moreover, it is hard to imagine that there were significant unintended consequences of urging people to put waste in trashcans.

\footnotetext{
${ }^{10}$ In this equilibrium, people might think better of people who took the environmental action, but the benefits of this might be small as long as the majority of people are thought to be altruistic anyway.

${ }^{11}$ Assume that the population share of the altruists is S. Altruists receive a benefit V from the environmental action; non-altruists receive no intrinsic benefit and the cost of the action is $C$ to both types. Both types also receive benefit $\mathrm{BP}$ if others think that they are pro-social with probability P. An "everyone litters" equilibrium exists as long as (1$\mathrm{S}) \mathrm{B}+\mathrm{V}<\mathrm{C}$, so the pro-social types don't deviate even if by deviating they would be thought to be pro-social with probability one. The "no one litters equilibrium" exists as long as $\mathrm{SB}>\mathrm{C}$, so that the selfish types don't deviate. These two equilibria both exist as long as $\mathrm{S}>\mathrm{Max}[\mathrm{C} / \mathrm{B}, 1+(\mathrm{V}-\mathrm{C}) / \mathrm{B}]$.

${ }^{12}$ In this situation, as opposed to the situation discussed in the previous footnote, the no one buys equilibrium may not stable given the implications that standard refinements make about off-the-equilibrium path beliefs.
} 
When it comes to carbon emission reductions, the downside of simple, observable actions is more significant. Driving less reduces emissions at least as readily as driving a standard hybrid, but driving a hybrid is observable while driving less is not. As such, the desire to appear environmental may actually lead to more carbon emissions rather than less, if people drive their hybrids around to show their environmental sensitivity. At their worst, these signaling equilibria can cause individuals to coordinate on behavior that is not particularly helpful and stifle debate about the activity, since anyone who argues might be seen as being less pro-social.

A third interpretation of environmental campaigns is that they influence preferences themselves, by increasing altruism towards the environment, creating a psychic benefit for specific pro-environmental activities or creating a psychic cost from anti-environmental activities. ${ }^{13}$ The distinction between internal motivation (created by preference formation) and external motivation (as in the signaling model) is connected to the classic sociological distinction between shame (which involves external sanctions) and guilt (which operates internally), as discussed by Kandel and Lazear (1992). If environmental campaigns were limited to inculcating general altruism, and then left individuals to figure out what that implies for their behavior, then they would have little potential to backfire, but they would also probably do little good either.

The suppliers of environmentalism appear to recognize the weakness of undirected altruism (Lorenzoni et al., 2007). While environmental empathy does seem to be a universal element of environmental campaigns, environmental campaigns rarely leave things at that. Almost universally, these campaigns then attempt to attach a behavioral implication to

\footnotetext{
${ }^{13}$ Stern (1992) summarizes the literature on the psychology of environmentalism. Stoll-Kleeman et al. (2001) discuss the psychological barriers that prevents environmental actions.
} 
environmental empathy, like not using pesticides or not littering or reducing carbon emissions or voting “Green."

Unlike signaling-based behavioral modifications, if environmental campaigns actually alter preferences, this will not create any bias towards observable behavior, but it may still lead towards simple behavioral directives, which is also true of traditional Pigouvian taxes. Nuanced directives will still be beyond the limits of powerful campaigns, for simpler advertising with shorter words is typically more effective (Bradley and Meeds, 2002). Ideally perhaps, global warming ads would encourage people to calculate the marginal impact of all of their actions on carbon emissions and to internalize the costs accordingly. Yet such analysis is beyond the cognitive ability of most individuals and complex instructions would seem to be a recipe for ineffectiveness. The need for simplicity and "small wins" (Weick, 1984) presumably explains why the anti-littering campaign may have been reasonably effective and why An Inconvenient Truth boils its message down to clear bullet points (consider buying a hybrid car).

Public policies can mitigate the hazards of environmental campaigns. Standard economic policies can also be abused, so I do not mean to suggest that standard interventions are universally better than endogenous preference formation. Rather, I mean to highlight the interaction between environmental persuasion and more classic policy interventions, such as Pigouvian taxes.

\section{Endogenous Environmentalism and Public Policy}

If campaigns only provide correct information to relatively rational individuals it is hard to see how they will do much harm. If the information misleads then there is more scope for harm, and harmful information seems more likely, when environmentalism suppliers are 
motivated by less than perfectly altruistic forces. ${ }^{14}$ For example, social losses may become more likely when environmentalists are motivated by primarily local, rather than global concerns, and local environmentalism may lead to beliefs and policies, like limits on local development, that make the community greener but the world browner.

Psychological interventions that stigmatize behavior, like driving low mileage cars, impose costs on drivers, like traditional Pigouvian taxes, but do not raise offsetting revenues (Loewenstein and O’Donoghue, 2006 and Glaeser and Ujhelyi, 2010). Psychic taxes can therefore be seen as inefficient substitutes for normal pecuniary taxes, since they impose costs on consumers but generate no offsetting revenues. By contrast, positive psychological feedback may create something of a psychic subsidy without cost to taxpayers. This difference creates an asymmetry between psychological taxes and subsidies that is absent with financial taxes and subsidies. While taxes may dominate stigma because they generate revenues, positive psychic rewards for good behavior dominate cash subsidies (of equivalent impact on behavior) because they do not require tax revenues. One quite tenable view is that since these issues are likely to remain difficult to assess they should be ignored, which is most justifiable if the psychic benefits of these campaigns are roughly equal to the psychic costs.

Finally, if environmental campaigns alter the equilibrium in a signaling model then the welfare implications are hopelessly muddled. Since Spence (1973), economists have known that signaling can be socially costly and it is certainly possible that some forms of signaling altruism through environmentalism do more harm than good. If the campaign moves all of society from one behavior to another, then it is sufficient to compare the global costs and benefits of the

\footnotetext{
${ }^{14}$ The public sector can of course broadcast competing bits of information, but that can also cause abuses. For example, a public sector intent on any particular policy agenda would have the incentive to convince voters that this agenda is green and the enormous resources of the public sector creates great potential for error.
} 
change in behavior. If the campaign moves society from a pooling equilibrium to a separating equilibrium, then there may also be some advantage from generating more information throughout the economy.

An added issue is that in a signaling model, individuals will have an incentive to show off their "green choices." If hybrid drivers like to show off their eco-cars, then this may lead to more driving which will counteract the benefit of reduced emissions per mile.

How does supplied environmentalism change the appropriate public policy? Normative theories of environmental responses typically take preferences and information as fixed, and impose few limits on tastes or knowledge. Unless the campaign directly informs individuals about the public policy, it is hard to see how conventional results would be overturned by preference changes, although the size of the Pigouvian tax change in supplied environmentalism changes the marginal social cost of an action.

The situation becomes somewhat more complex if the campaign creates a signaling equilibrium, which can lead to perverse results. Berman (2000) shows that in signaling games, a subsidy can increase the extremity of signaling behavior. In a separating equilibrium, the cost of distorting behavior times the amount of distortion must be high enough to deter the anti-social types from imitating the pro-social types. If the costs of distorting behavior decline, then the amount of distortion may have to rise, implying the carbon taxes will lead pro-social types to buy even more low mileage vehicles to signal their altruism. Moreover, if the full social cost of carbon is charged in tax, then there is no social advantage from further environmentalism. This logic suggests if environmentalists are signaling, then Pigouvian taxes should be lower than traditional logic would suggest. 
The final and most tricky issue is the impact that public policy choices can have on the supply of environmentalism. In Glaeser (2005), I argued that constitutional barriers to racebased policies limited the tendency of politicians to spread hatred against different races. Whenever an issue becomes more policy-relevant, there is more incentive for interested parties to invest in belief and preference formation and that is true for the environment as well.

This endogenous supply of environmental beliefs and preferences provides another reason to treat Pigouvian taxes differently from cap-and-trade responses to risks of climate change. If policy interventions are limited to cap-and-trade, then the private sector is likely to face fewer losses from environmental policies than if policies also include carbon taxes. If businesses have less to lose from environmental policies, then they also have less incentive to fight those policies by investing in anti-environmental campaigns.

\section{Jevons Redux: Hybrid Cars and Behavioral Responses}

Among the most visible "environmental" actions is to own a hybrid or electric car. Low mileage vehicles have long been touted as environmentally sensitive choices, by environmental activists (such as former Vice President Gore). As discussed above, these interventions can be seen as providing information, forming a preference for hybrid cars, or an attempt at signaling equilibrium where pro-social people signal their benevolent nature by driving hybrids.

The supply of this form of environmentalism seems to have its roots in the self-interested advertising of car companies. During the gas crisis of the 1970s, Gremlin ads promised to “Relieve the Fuel Shortage,” and Honda’s 1978 advertisement, “Gasoline Made Simple,” mentioned the Civic's 47 miles per gallon on the highway. Yet these were appeals primarily to 
self interest, not inculcating environmental activism. Honda also proudly proclaimed that the car was made without a catalytic convertor so it could use leaded gas. Datsun perhaps came closest to appealing to altruistic environmental motives by claiming that the Datsun 1200 could "help ease our energy crisis," but even there, the ad's real focus on was on "another important resource: your money.”

Private incentives and more altruistic motives came together when Toyota introduced its Prius to the U.S. in 2001, noting its support from the Sierra Club and the National Wildlife Federation. ${ }^{15}$ As gas prices and concern with global warming both rose, the Prius’ environmental focus became an increasingly valuable asset, helping the car to become a bestseller. Nissan Leaf advertisements sell their product not based on driving experience, but with a dystopian vision where every appliance runs on gasoline, and suggest that buying a Leaf offers a better path for the planet.

The sales of high mileage hybrid or electric cars are assisted by financial incentives and regulations, such as CAFE standards, but they are also sold with the help of environmental rhetoric, provided both by environmental advocates and the car companies themselves. An Inconvenient Truth urges motorists to buy a hybrid or an electric car, and this appears to be one of the rules of thumb now endorsed by many environmentalists.

These investments in influence can be seen as either creating psychic costs to driving a traditional car or a psychic benefit from buying a Prius or a Leaf. Prius' appear to command a price premium over comparable Toyota models, even controlling for fuel consumption (Baltas and Saridakis, 2010), which supports the idea that consumers are receiving some form of hedonic

\footnotetext{
${ }^{15}$ Halbright and Dunn (2010).
} 
or signaling value from the car. The tendency of environmentalists to own hybrid cars (Kahn, 2007) also suggests that they are perceived as doing good for the environment.

The impact of these campaigns on welfare depends on both the direct psychic impact on individuals and the environmental impact of the policy, which is in turn related to the classic Jevons paradox. If the campaigns work as a psychic tax on driving non-hybrid cars, then the "lost revenue” point discussed above is relevant. If they work as a psychic surplus to driving hybrids, then that benefit may distort behavior by inducing too much driving. ${ }^{16}$ I will not attempt to assess the direct psychic costs or benefit of any preference changes or the waste involved in signaling, even though such concerns are theoretically important to assessing the overall social impact of these campaigns.

In 1865, William Stanley Jevons wrote that “new modes of economy will lead to an increase of consumption,” and “an improvement of the engine, when effected, will only accelerate anew the consumption of coal.” Jevons’ The Coal Question notes that before Smeaton and Watt, 84 pounds of coal were able to lift 5.59 million pounds of water one foot high. In 1776, Watt's separate condenser engine meant that the same amount of coal could lift more than 20 million pounds of water, and by the 1860s, engine efficiency had doubled again. Despite these technological improvements in fuel efficiency, Jevons estimates that English coal consumption increased eight-fold from 1801 to 1861 from ten to over eighty million tons.

To assess the environmental impact of the campaign, the question becomes the behavioral response as lower per mile costs increase driving, which is typically called the rebound effect (e.g. Greening, Greene and Difiglio, 2000). Typically the rebound effect of

\footnotetext{
${ }^{16}$ Purely from introspection, I suspect that these campaigns have provided more psychic benefits to hybrid drivers than costs to non-drivers which means that they may end up being benign.
} 
increasing gas mileage is the elasticity of miles travelled with respect to miles per gallon. If that effect is greater than one, then improved mileage means more environmental harm. One survey finds that long run elasticities range from .6 to .8 while short run elasticity run from .2 to .3 (Graham and Glaister, 2002) L Long run elasticities allow car drivers to alter the fuel efficiency of their vehicles, which means that they may be less relevant to assessing the impact of changing fuel efficiency itself. Small and Van Dender (2007) estimate the total "rebound effect” and estimate that the long run effect has dropped from 20 percent to 10 percent, which is compatible with other studies finding a decreased sensitivity of driving to fuel prices (Hughes, Knittel, and Sperling, 2006). These relatively low behavioral responses suggest that Jevons may not be that relevant when it comes to a taste for a more efficient gas powered cars, but a taste for hybrid and electric cars may make his wisdom more relevant again.

But hybrid or electric cars use energy that is often produced by something other than petroleum and that impacts the rebound effect. Assuming that there is a constant elasticity of miles travelled with respect to pecuniary cost leads to the general formula that a new technology

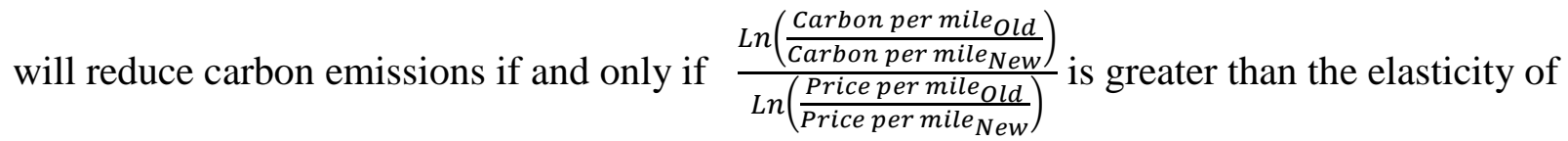
miles travelled with respect to price.

The ratio of the change in log energy use per mile divided by the change in the log price per mile must be greater than the elasticity of miles travelled with respect to price. When the two ratios are identical, as in the case of purely gas-powered cars, then the familiar result that the elasticity must be less than one reappears for reductions in mileage to reduce gas consumption or carbon emissions, but when the price impact is greater than the carbon impact, then the elasticity will have to be significantly less than one. 
In the case of gas cars, the price per mile is per gallon divided by miles per gallon. For a car which drives at 33.3 miles per gallon, which seems like a reasonable estimate for newer vehicles comparable with standard electric cars, the energy costs of driving 100 miles is $\$ 10.18$, assuming a per gallon cost is around the 2012 price of $\$ 3.39 .{ }^{17}$

In the case of an electric car, the relevant price is price per kilowatt hour divided by miles per kilowatt hour. The average 2012 price per kilowatt hour was 12.7 cents. Current reports suggest that the Nissan Leaf, a purely electric car, averages 3 miles per kilowatt hour of electricity. ${ }^{18}$ Scholars typically assume that energy efficiency for electric vehicles will rise to four or even five miles per kilowatt hour (Lemoine, Kammen, and Farrell, 2008 and Lee and Lovellette, 2008). If electric cars are able to go four miles per kilowatt hour, then the cost of travelling 100 miles, assuming four miles per kilowatt hour, is $\$ 3.18 .{ }^{19} \quad$ These figures imply that $\operatorname{Ln}\left(\frac{\text { Price per mile }_{\text {old }}}{\text { Price per mile }_{\text {New }}}\right)$ equals 1.16. Electric cars are substantially less expensive to drive per mile, and that difference will only increase if the gas prices continue to rise relative to the cost of providing electricity.

For the environmental damage figures, I look only on carbon emissions costs. Since the ratio is important, not the absolute quantities, I do not have to take a standard of the social cost per carbon emitted. In the case of gas-powered cars, I have already assumed a 33.3 mile per gallon figure. The Department of Energy estimates 19.564 pounds of carbon dioxide per gallon of gas. To take account of the emissions involved in refining and delivering gasoline, it is typically to inflate that estimate by 20 percent or so, which implies 23.46 pounds of carbon dioxide per gallon or 70.38 pounds of carbon dioxide to drive 100 miles.

\footnotetext{
${ }^{17}$ National Bureau of Labor Statistics (June 2013)

${ }^{18}$ Consumer Reports (April 2011) and Austin (2010) .

${ }^{19}$ U.S. Energy Information Administration (March 12, 2013).
} 
To calculate the carbon emissions associated with electric driving, I use the eGrid estimate of 1.3 pounds of carbon dioxide per kilowatt hour. ${ }^{20}$ If I assume, as some authors do, that the extra electricity needed to power cars will have to be provided by fossil fuels, rather than hydroelectricity or solar power, then the carbon emissions per kilowatt hour rises to 1.75 pounds. In the first case, a four mile per kilowatt hour car will produce 32.5 pounds of carbon dioxide to drive 100 miles, which means that $\operatorname{Ln}\left(\frac{\text { Carbon per mile } \text { old }}{\text { Carbon per mile }_{N e w}}\right)$ equals 0.77 . In this case, the electric car benefits the environment as long as $\sigma$ is less than .66, which is more stringent than the usual requirement for fuel efficiency to improve carbon emissions, but still likely to hold.

If, however, the relevant carbon emissions are 1.75 pounds per kilowatt hour, then the same car will produce 43.75 pounds of carbon dioxide per hundred miles and

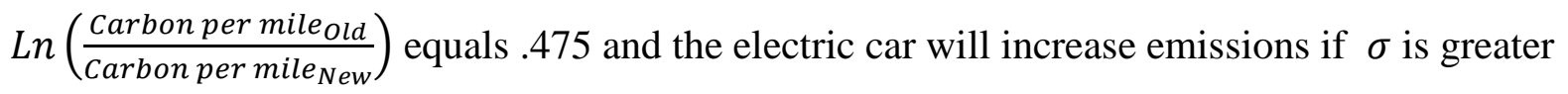
than .41. In this case, it becomes plausible that the electric car will actually lead to more, not less, carbon emissions because the reduction in price per mile is much stronger than the reduction in the environmental damage per mile. The downside of electric cars will be exacerbated if electric car owners drive more to show off their eco-friendly transport.

If environmental campaigns work through information or preference formation, then there is little change in the optimal Pigouvian taxes, which should remain based on the estimates of the externalities from driving. If hybrid cars have become a signal, then there is at least the possibility that by lowering the marginal cost of owning a hybrid, the tax will lead pro-social signalers to engage in more extreme environmental behavior. This effect can increase the returns

\footnotetext{
${ }^{20}$ Environmental Protection Agency (2011).
} 
to higher taxes, if the taxes are far below the optimal level, or reduce it, if the tax is set to equal the full environmental externality.

\section{Darby Redux: Simple Conservation Rules}

A second reason that conservation rules can create an offset is the behavior of suppliers. Supply-side effects have been emphasized both in the environmentally-relevant areas of recycling (Darby, 1973) and protection of endangered species, such as elephants (Kremer and Morcom, 2000). In the case of conservation, the problem is that recycling can be harmful or beneficial, but since environmental indoctrination generates a broad preference or norm, it cannot differentiate between good or bad recycling behavior.

Recycling and conservation, like hybrid cars, have been subjects of intense environmental campaigning, which often focus on separating out recyclables or limiting consumption of goods, like paper. In both cases, the norm or preference becomes either a psychic or social tax on the use of the primary commodity, or a subsidy for using the recycled product. Television campaigns, and even children’s books like Dr. Seuss' “The Lorax,” aim at inculcating thriftier sensibilities. While many of these campaigns are presumably motivated by purely altruistic motives, recycling companies have been sponsors of environmental activities, like Earth Days, and they may have less benevolent motives.

In evaluating the social effects of these campaigns, Darby (1973) demonstrates that there is a key difference between resources that are in fixed supply in a common pool and renewable. If there is a common pool where entrepreneurs cannot independently produce the good, then a taste for conservation represents a possible alternative to other interventions, such as taxing 
supply or assigning property rights over the pool. The created taste limits consumption of the good, and in cases like fish or trees, this limited consumption may allow the stock to naturally replenish itself. Moreover, the taste for recycling may be more effective than a tax because it doesn't require the external enforcement of hard-to-monitor recycling behavior.

The situation is largely reversed when the commodity is essentially produced by private suppliers. When paper is largely produced by commercial forest, then reduced demand for paper will also reduce the incentive to plant trees. The impact of this simple behavioral rule is to lower the global quantity of the resource, just as widespread vegetarianism will lower the stock of meat-producing animals.

Ideally, recycling or conservation preferences could differentiate between these two very different settings, but the relatively coarse nature of public campaigns means that there is a common norm, and it is applied globally without much attention to whether the effects are benign or not. In a mixed situation, the benefits of the preference depend on the environmental value of stocks of private or public resources. Today, U.S. timber production comes overwhelmingly (over 99 percent) from private, not national, forests. ${ }^{21}$ As such, there is little possibility that greater paper use is eliminating a commonly held resource.

Advocates of recycling emphasize the difference from "old growth" forests and newer growth forests, and emphasize that the problem with logging is the elimination of old growth forests. While accurate measurement is difficult, in part because of the uncertain definitions of old growth forests, America has relatively little old growth forest in private hands (Best and

${ }^{21}$ (U.S. Department of Agriculture, 2013) 
Wayburn, 2001), which suggests that a very small fraction of America's wood-product production is coming from such forests. ${ }^{22}$

In the case of recycling, there is a particularly interesting interaction between environmental campaigns and policy interventions. An intervention that protects virgin forests can have the perverse effect of changing pro-recycling campaigns from benign to harmful. This is a case in which standard economic policies may be strong substitutes for environmental campaigns, subsidizing the consumption of paper to induce more foresting, essentially reversing the impact of the environmental campaign.

\section{The Global Impact of Local Environmentalism}

I now turn to an area that has been less explored by economists: the perverse effects of local environmental campaigns. In the previous cases, the downsides of environmental campaigns came from adopting simple rules which did not fully internalize total externalities. In this case, the incentives of local environmentalists to preserve their own environment may run directly counter to more global goals of reducing carbon emissions.

At the very beginning of the American environmental movement, John Muir and Theodore Roosevelt both worked for the protection of natural land against development. Initially that movement focused on truly wild areas in the American interior, but gradually, the move to conserve land came into the heart of American metropolitan areas. For example, in 1961, the Save the Bay movement was started in Berkeley “to stop the City of Berkeley's plan to

\footnotetext{
${ }^{22}$ Canadian wood is more likely to come from the country's boreal forests.
} 
double in size by filling in the shallow Bay off-shore.”23 While Save the Bay focused on protecting waterways, other environmental groups focused on preserving open spaces within greater San Francisco. ${ }^{24}$ The Friends of Mammoth case of 1973 was perhaps the signal success of this movement; for the case required all significant private developments in California to undertake an environmental impact review.

Other states also have powerful local environmental movements that worked to preserve green spaces and wetlands within metropolitan regions. Glaeser and Ward (2009) document the steady increase in the number of communities within greater Boston who have rules pertaining to wetlands that go beyond the state’s already significant regulations. Accompanying explicit environmental barriers are minimum lot sizes that reach 60 acres in some parts of the San Francisco region, which are also justified, in part, as preserving open space.

While environmental rhetoric is ubiquitous in battles against new suburban construction, one reasonable view is that local residents dislike new construction, because it creates congestion or lowers local housing values, and they oppose it using any arguments that are at hand.

Opposition to new construction may reflect a certain type of environmentalism-- a preference for nearby greenery over new homes — but that is not equivalent to taking the broader interests of the planet to heart. It does seem likely, though, that the environmental barriers on building imposed by the Friends of Mammoth case reflected environmental beliefs of the judiciary, which were formed in part by the longer term activity of the environmental movement.

Local land use policies might do a good job of internalizing local and global externalities. If local land use controls acted to correct local externalities, then standard urban theory predicts

\footnotetext{
${ }^{23}$ Save the Bay, 2013.

${ }^{24}$ Henry, Lubell and McCoy (2011) describe how social networks influence land use planning in California.
} 
that they should be maximizing local land values (Arnott and Stiglitz, 1979). If we think of these barriers as just limiting the level of density within a community, then the total value of each unit of land equals the density of homes in that area times the price of each home minus construction costs or (Price(Density)-Cost)Density, where Cost represents actual construction costs. The level of density that maximizes total land value (which is home price minus construction cost) will satisfy $\frac{\text { Price-Cost }}{\text { Price }}=-\frac{\text { Density }}{\text { Price }} \frac{\partial \text { Price }}{\partial \text { Density }}$, or the price markup over cost should equal the elasticity of price with respect to density. This formula is essentially the standard Pigouvian tax formula, assuming that land value captures total social value.

Glaeser and Ward (2009) attempt to compare price mark-ups with the elasticity of price with respect to density in greater Boston. We find the price markups are often close to 50 percent, while the density elasticities are typically no more than 10 percent. We concluded that it was unlikely that local land use restrictions were effectively maximizing land values, at least in greater Boston, although they may still be optimal. Many environmentalists would argue that focusing on human benefits is an error because the primary reason to save the wetlands is to help the non-human inhabitants of those ecosystems. Alternatively, the use of property values to assess welfare gains may miss benefits for infra-marginal residents that are not reflected in property values.

In principle, bargaining should ensure that activists internalize the interests of land owners, but bargaining failures surely exist given the difficulties of making side payments in politics. Local property values may also be suboptimal because the benefits, and costs, of an intervention may be felt far beyond the area. An area with an attractive fixed resource can 
operate as a standard monopolist, restricting the supply of its product —in this case housing —and thereby raising its price and imposing costs on would-be consumers.

Local land use regulations that are motivated by local environmental reasons may even harm the larger environment. Local communities can’t change the total amount of new construction within the U.S., but they can make sure that this construction takes place somewhere else, perhaps somewhere that typically has higher carbon emissions.

Glaeser and Kahn (2010) estimate the net impact on carbon emissions of building in different areas of the United States. We attempt to implement this thought experiment by first calculating the carbon emissions associated living in different parts of the country for a standardized household. We estimate household energy usage from electricity and home heating and energy used in transportation. We are not able to factor in workplace emissions.

If an area blocks this family from moving in, then the net impact on carbon emissions of that restriction is the expected amount of carbon that the family will emit living elsewhere minus the expected amount of carbon that the family will emit by living in the community. A standardized household produces 19.4 tons of carbon dioxide per year in San Francisco. If a new housing unit is blocked in San Francisco, I assume that it gets randomly allocated throughout the U.S., where the probability of having the new household is based on the recent population growth of the area. Such a randomly allocated home has expected carbon dioxide emissions of 27.33 tons per year. If a home is located in suburban Texas instead of Berkeley, it can expect to emit a lot more carbon, primarily because of hotter summers.

If our building strategy was meant to minimize carbon emissions, we would want to ban building in Texas and build it instead around Berkeley. Of course, that is not the only 
environmental reason to ban local building and this calculation does not imply that California land use regulations are inappropriate. Yet it is possible that local restrictions may have global implications and those implications may run deeply against the spirit of the local interventions. Indeed, the appropriate public policy response may be either to subsidize building in San Francisco or to tax construction in more carbon intensive parts of the country.

The environmental slogan "think globally, act locally" has such power because it offers a planetary mission with local tangible objectives. The emotional side of environmentalism will always tend to favor nearby actions. Yet such nearby actions may be quite counter-productive from a planetary perspective, because local actions can have systemic side-effects that work in the opposite direction.

\section{Competition in the Market for Ideas and Environmental Outcomes}

If environmental ideas are supplied by entrepreneurs, like John Muir and Rachel Carson, and debated by others, then economic market analysis should help us understand why there are dramatic belief differences across time and space. According to the Pew Global Attitudes Project, 90 percent of Brazilians but only 44 percent of Americans believe that global warming is a very serious problem. ${ }^{25}$ Perhaps that difference can be explained by Brazil’s generally warmer temperature, but it's harder to know why 68 percent of the French but only 30 percent of the Chinese classify the global warming problem as very serious.

\footnotetext{
${ }^{25}$ Pew Research Global Attitudes Project (2009)
} 
While Pew's Survey question surely captures the degree of concern about global warming, those differences don’t imply that people genuinely believe different scientific facts or that influence shaped beliefs. The U.S. data is somewhat clearer on both counts, because Pew asks respondents "is there solid evidence the earth is warming" and for those who said yes, asks them whether human activity or natural patterns are responsible for the change. In a standard economic model, with rational Bayesian learners, answers to these questions should be relatively uniform since everyone has access to the same core body of public evidence.

Yet, of course, opinions differ wildly across population subgroups and even over time (Weber and Stern, 2011). Seventy-seven percent of Democrats and 84 percent of liberal Democrats believe that there is solid evidence for global warming, while 43 percent of Republicans and 31 percent of conservative Republicans share that view. In 2007, 77 percent of respondents said that there was solid evidence that the earth was warming and 47 percent of respondents credited human activity. Only 16 percent said that there wasn't solid evidence for global warming. Only two years later, 33 percent of respondents said that there was no solid evidence for global warming and only 57 percent said that there was solid evidence. ${ }^{26}$

The Pew evidence certainly doesn't prove that parties shape environmental beliefs, but it does suggest that people with different beliefs are choosing different political parties. As Kahn and Matsusaka (1997) have already shown, there is a connection between environmentalism and other political views. Al Gore's An Inconvenient Truth illustrates the major investment that some party leaders have made to influence people’s environmental beliefs, and certainly many prominent Republicans have promulgated their own more negative view of global warming.

${ }^{26}$ Pew Research Center for the People \& the Press (2011) 
Left and right wing media both promulgate the environmental viewpoint that complements their views.

Formal economic tools can help us understand why political actors invent in shaping beliefs about the environment, just as they can help us understand why some political leaders spread ethnic stereotypes (Glaeser, 2005). Leaders will promote environmental causes if they complement their other policies. Socialists who want to regulate businesses for many reasons may also suggest that business is causing environmental harm. In the U.S., both parties maintained an environmental consensus through the 1970s; both Nixon and Carter had major environmental initiatives, but Nixon never ran as an economic libertarian. He tried to offer lawand-order and different foreign policies, but these were not complements with less environmental regulation.

By contrast, Reagan opposed environmental regulations, as part of a general push against big government. Naturally his laissez-faire orientation led him to minimize environmental threats, most famously with his line that "trees cause more pollution than automobiles do.” The environmental gap between the parties narrowed under George H.W. Bush and Clinton, both of whom moved their parties’ economic programs to the center, but then widened in the 2000 election, as George W. Bush promoted a more muscularly Reaganesque Republicanism. Since 2000, the parties have increasing divided on energy and environmental issues, and Democrats, like Al Gore, have emphasized environmental threats while Republicans have disparaged potential dangers from global warming.

Just as political incentives help us to understand many of these broad patterns in climaterelated beliefs, political incentives also may help us understand the differences in countries' 
beliefs about global warming. Alesina and Glaeser (2004) discuss the historic and demographic forces that led to a far more empowered right in the United States than in Continental Europe. Since global warming complements regulation, more left-wing pro-regulation countries, like France and Brazil, have empowered political actors who promote that viewpoint.

Economists have long written models where human beings were hyper-rational, but there is a growing body of evidence that suggests significant limits on cognition. The profound differences in environmental opinions across groups and time is another piece of evidence against hyper-rational humanity. But these deviations from normal economic models don't mean that economic models aren’t still relevant. Indeed, if beliefs are supplied, then economics offers the best chance of understanding why and when they are supplied.

\section{Conclusion}

Human beings are not hyper-rational solely-self-interested agents, and that truth is certainly evidenced in the environmental field. People pay a premium for products that are sold as being good for the planet, but they don't always do a great job figuring out which products are really green. Opinions about scientific topics, like global warming, differ far too much to be explained by standard Bayesian models.

But limits to human cognition do not make economics irrelevant. In many cases, they make economics even more important. Environmental ideas can achieve a wide following, and they can certainly lead to less than perfect outcomes, particularly because of systemic behavioral consequences. High mileage electric cars may lead to substantial increases in driving. 
Recycling may lead to fewer private forests. Stopping construction in Berkeley may lead to more construction in Houston and an increase in carbon emissions.

The economic approach to the environment has, since Jevons, emphasized the understanding of behavioral responses. Those tools can also be used to understand the implications of environmental impulses, whether rational or not. Those tools can help us understand why different people supply different environmental ideas. Economics continues to have much to offer the environment, especially if it embraces both traditional theory and psychological realism.

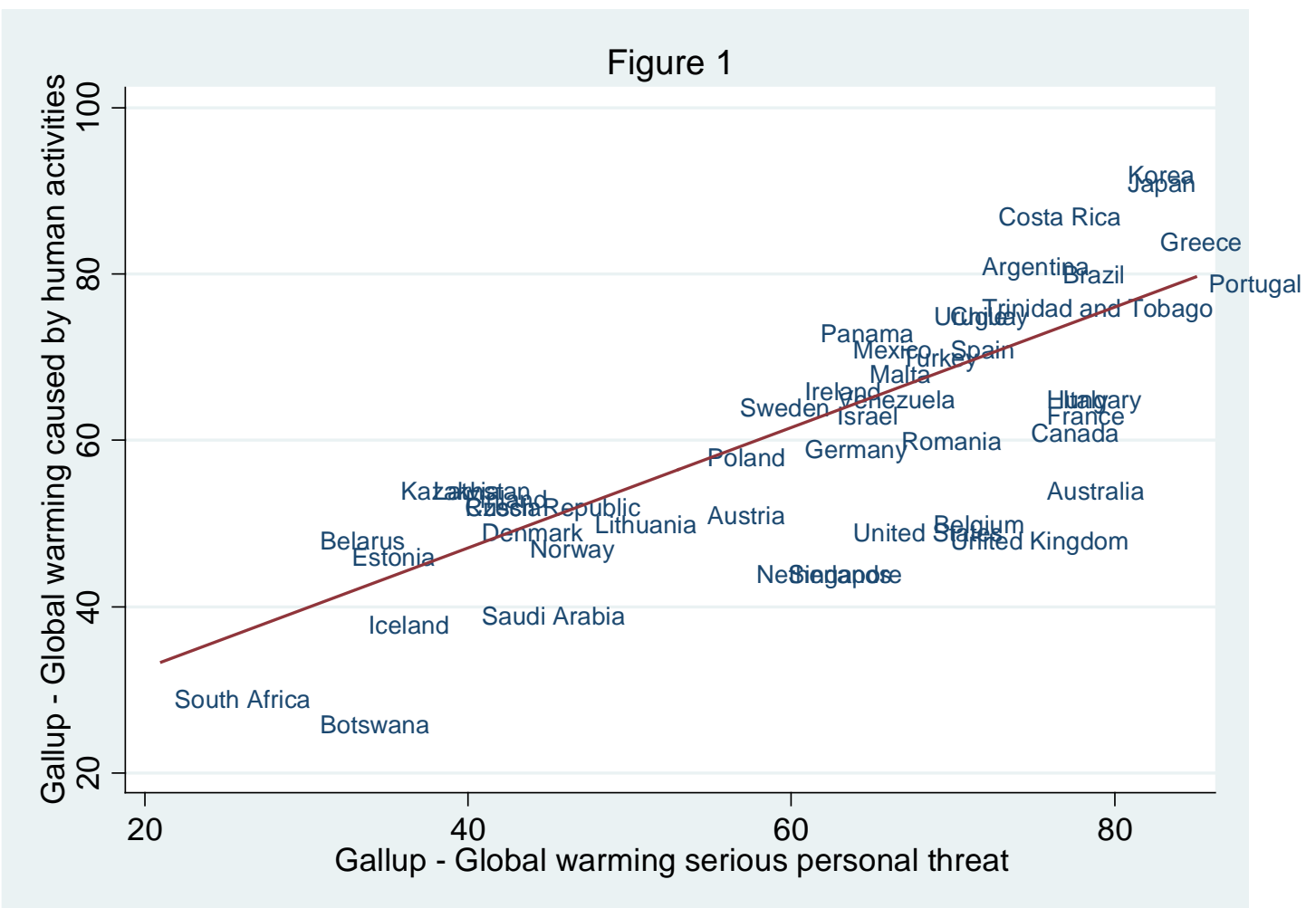




\section{References}

“A bad climate for development.” The Economist September 17, 2009.

http://www.economist.com/node/14447171

Alesina, Alberto and Edward Glaeser. 2004. Fighting Poverty in the US and Europe: A World of Difference. Oxford University Press.

Althaus, Scott L. 1998. "Information effects in collective preferences." American Political Science Review. 92(3): 545-558.

Arnott, Richard J., and Joseph E. Stiglitz. 1979. “Aggregate land rents, expenditure on public goods, and optimal city size.” Quarterly Journal of Economics 93, (4): 471-500.

Asch, Solomon E. 1955. "Opinions and social pressure." Scientific American 193: 31-35.

Aumann, Robert J. 1976. “Agreeing to Disagree.” Annals of Statistics. 4(6): 1236-1239.

Austin, Michael. "Electric Revival: Better not Leaf us stranded.” Car and Driver October 2010. http://www.caranddriver.com/reviews/2011-nissan-leaf-sl-short-take-road-test

Baltas, George and C. Saridakis. 2010. "Measuring brand equity in the car market: a hedonic price analysis,” Journal of the Operational Research Society. 61: 284 - 293.

Basu, Paroma. “Third World bears brunt of global warming impacts.” University of MadisonWisconsin News. November 16, 2005.

Berman, Eli. 2000. 'SSect, Subsidy and Sacrifice: An Economist's View of Ultra-Orthodox Jews.’ Quarterly Journal of Economics. CXV: 905-953.

Best, Constance and Laurie A. Wayburn. 2001. America's private forests: status and stewardship. Island Press.

Bradley, Samuel D. \& Meeds, Robert. 2002. "Surface-structure transformations and advertising slogans: The case for moderate syntactic complexity.” Psychology \& Marketing. 19: 595619.

Carson, Rachel. Silent Spring. Houghton Mifflin, 1962.

Clifford, Stephanie and Andrew Martin. “As Consumers Cut Spending, 'Green’ Products Lose Allure.” New York Times April 21, 2011. http://www.nytimes.com/2011/04/22/business/energyenvironment/22green.html?_r=0\&adxnnl=1\&pagewanted=all\&adxnnlx=1364324434P40d6Phh7b2fmmx7VakY9A 
Darby, Michael R. 1973. "Paper Recycling and the Stock of Trees." Journal of Political Economy. 81(5): 1253-1255.

Earle, Richard. 2002. The Art of Cause Marketing: How to Use Advertising to Change Personal Behavior and Public Policy. McGraw-Hill.

Environmental Protection Agency. 2011. eGrid2010 Version 1.1 Year 2007 Summary Tables. http://www.epa.gov/cleanenergy/documents/egridzips/eGRID2010V1_1_year07_SummaryTable $\underline{\text { s.pdf }}$

Glaeser, Edward, 2005. “The Political Economy of Hatred,” Quarterly Journal of Economics. 120 (1) : 45-86.

Glaeser, Edward L., and Gergely Ujhelyi. 2010. "Regulating misinformation.” Journal of Public Economics. 94(3-4):247-257.

Glaeser, Edward L., and Matthew E. Kahn. 2010. "The Greenness of Cities: Carbon Dioxide Emissions and Urban Development." Journal of Urban Economics. 67(3): 404-418.

Glaeser, Edward L., Bruce I. Sacerdote, and Jose A. Scheinkman. 2003 "The Social Multiplier." Journal of the European Economic Association.1(2-3): 345-353.

Glaeser, Edward L., and Bryce A. Ward. 2009. "The Causes and Consequences of Land use Regulation: Evidence from Greater Boston." Journal of Urban Economics. 65(3): 265278.

Goeree, Jacob K., Charles A. Holt and Susan K. Laury. 2002. "Private costs and public benefits: Unraveling the effects of altruism and noisy behavior.” Journal of Public Economics 83(2): 257-278.

Graham, Daniel J., and Stephen Glaister. 2002. "The Demand for Automobile Fuel: A Survey of Elasticities." Journal of Transport Economics and Policy. 36(1): 1-26.

Greening, Lorna A., David L. Greene, Carmen Difiglio. 2000. "Energy efficiency and consumption — the rebound effect — a survey.” Energy Policy. 28(6-7):389-401

Halbright, Rudi and Max Dunn. 2010. "Case Study: The Toyota Prius, Lessons in marketing ecofriendly products."

http://www.maxdunn.com/files/attachments/maxdunn/PMBA:\%20Presidio\%20MBA\%2 $\underline{\text { OHome/Prius_Marketing_Case_Study.pdf }}$

Hilgartner Stephen and Charles L. Bosk, and. 1988. "The Rise and Fall of Social Problems: A Public Arenas Model.” The American Journal of Sociology, 94(1): 53-78.

“History.” Save the Bay, accessed August 15th 2013, http://www.savesfbay.org/history. 
Henry, Adam Douglas, Mark Lubell, and Michael McCoy. 2011. "Belief Systems and Social Capital as Drivers of Policy Network Structure: The Case of California Regional Planning." Journal Of Public Administration Research \& Theory 21(3): 419-444.

Hughes, Jonathan E., Knittel, Christopher R. and Sperling, Daniel. 2006. "Evidence of a Shift in the Short-Run Price Elasticity of Gasoline Demand.” NBER Working Paper.

"Initial impressions: Nissan Leaf.” Consumer Reports April 2011. http://www.consumerreports.org/cro/magazine-archive/2011/april/cars/nissanleaf/overview/index.htm

Jacoby, William G. 2000. "Issue Framing and Public Opinion on Government Spending.” American Journal of Political Science 44(4): 750-767.

Jevons, William Stanley. 1865. The coal question: an enquiry concerning the progress of the Nation, and the probable exhaustion of our coal-mines. London: Macmillan.

Kahn, Matthew E. 2007. "Do Greens Drive Hummers Or Hybrids? Environmental Ideology as a Determinant of Consumer Choice." Journal of Environmental Economics and Management. 54(2): 129-145.

Kahn, Matthew E. and John G. Matsusaka. 1997."Demand for Environmental Goods: Evidence from Voting Patterns on California Initiatives," Journal of Law and Economics. 40(1): 137-73.

Kandel, Eugene and Edward P. Lazear. 1992. "Peer Pressure and Partnerships.” Journal of Political Economy , 100(4): 801-817.

Kremer, Michael, and Charles Morcom. 2000. "Elephants." American Economic Review. 90(1): 212-234.

Lee, Henry and Grant Lovellette. 2008. "Will Electric Cars Transform the U.S. Vehicle Market? An Analysis of the Key Determinants.” Belfer Center Discussion Paper, Harvard Kennedy School.

Lee, Nancy and Philip Kotler. 2006. Marketing in the Public Sector: A Roadmap for Improved Performance. Wharton School Publishing.

Leiserowitz, Anthony. 2006. "Climate Change Risk Perception and Policy Preferences: The Role of Affect, Imagery, and Values.” Climatic Change 77(1-2): 45-72.

Lemoine, D.M., D.M. Kammen, and A.E. Farrell. 2008. "An innovation and policy agenda for commercially competitive plug-in hybrid electric vehicles.” Environmental Research Letters. 3(1):014003. 
Loewenstein, George, and Ted O'Donoghue. 2006. "We Can Do This the Easy Way or the Hard Way: Negative Emotions, Self-Regulation, and the Law.” University of Chicago Law Review. 183.

Lorenzoni, Irene, Sophie Nicholson-Cole, and Lorraine Whitmarsh. 2007. "Barriers perceived to engaging with climate change among the UK public and their policy implications.” Global Environmental Change. 17(3-4): 445-459.

Lorenzoni, Irene, and Nick F. Pidgeon. 2006. "Public views on climate change: European and USA perspectives." Climatic Change 77(1-2): 73-95.

“Lumber Production Trends:” Forest Products Laboratory, US Department of Agriculture, accessed August 15th 2013, http://www.fpl.fs.fed.us/research/units/economics_trends.shtml

Massachusetts Department of Education. 2006. "Pre-Kindergarten-High School Standards.” Massachusetts Science and Technology/Engineering Curriculum Framework. http://www.doe.mass.edu/frameworks/scitech/1006.pdf

Metrick, Andrew, and Martin L. Weitzman. 1996. "Patterns of Behavior in Endangered Species Preservation." Land Economics. 72(1): 1-16.

Mutz, Diana C. and Paul M. Martin. 2001. "Facilitating Communication across Lines of Political Difference: The Role of Mass Media.” American Political Science Review 95(1):97-114.

National Bureau of Labor Statistics. “Average Energy Prices, Los Angeles Area-June 2013.” News release, July 19, 2013. http://www.bls.gov/ro9/cpilosa_energy.pdf

Nelson, Thomas E. and Donald R. Kinder. 1996. “Issue Frames and Group-Centrism in American Public Opinion” The Journal of Politics 58(4): 1055-1078.

Nordhaus, William.D. 1994. "Expert opinion on climatic change.” American Scientist 82(January-February): 45-51.

Oskamp, Stuart, Maura J. Harrington, Todd C. Edwards, Deborah L. Sherwood, Shawn M. Okuda, and Deborah C. Swanson. 1991. "Factors Influencing Household Recycling Behavior." Environment and Behavior. 23(4): 494-519.

Pew Research Center for the People \& the Press. "Modest Rise in Number Saying There Is 'Solid Evidence’ of Global Warming” Released December 1, 2011. http://www.peoplepress.org/2011/12/01/modest-rise-in-number-saying-there-is-solid-evidence-of-globalwarming/

Pew Research Global Attitudes Project. "Confidence in Obama Lifts U.S. Image Around the World.” Released July 23, 2009 http://www.pewglobal.org/2009/07/23/chapter-9environmental-issues/ 
Polonsky, Michael J., and Alma T. Mintu-Wimsatt. 1995. Environmental marketing: strategies, practice, theory, and research. Psychology Press.

Shogren, Jason F., and Laura O. Taylor. 2008. "On Behavioral-Environmental Economics." Review of Environmental Economics and Policy. 2(1): 26-44.

Slovic, Paul. 2000. The Perception of Risk. (Earthscan:Virginia).

Small, Kenneth A., and Kurt Van Dender. 2007."Fuel Efficiency and Motor Vehicle Travel: The Declining Rebound Effect." Energy Journal. 28(1): 25-51.

Spence, Michael. 1973. "Job Market Signaling." Quarterly Journal of Economics 87 (3): 355374.

Stern, Paul C. 1992. "Psychological dimensions of global environmental change." Annual review of psychology 43(1): 269-302.

Stoll-Kleemann, S., Tim O’Riordan, and Carlo C. Jaeger. 2001. "The psychology of denial concerning climate mitigation measures: evidence from Swiss focus groups.” Global Environmental Change 11(2): 107-117.

U.S. Energy Information Administration. "Short-Term Energy Outlook.” Released March 12, 2013. http://www.eia.gov/forecasts/steo/

Van Liere, Kent D. and Riley E. Dunlap. 1980. “The Social Bases of Environmental Concern: A Review of Hypotheses, Explanations and Empirical Evidence.” Public Opinion Quarterly. 44(2): 181-197.

Weber, Elke U., and Paul C. Stern. 2011. "Public understanding of climate change in the United States." American Psychologist 66(4): 315-328.

Weick, Karl E. 1984. "Small wins: Redefining the scale of social problems.”American Psychologist 39(1): 40-49.

Whitmarsh, Lorraine. 2009. "What's in a name? Commonalities and differences in public understanding of 'Climate Change' and 'Global Warming'." Public Understanding of Science 18(4): 401-420. 